УДК 32+504:316.32

https://doi.org/10.34142/24130060.2019.18.2.09

\title{
ДО ПИТАННЯ ДЕРЖАВНОЇ БЕЗПЕКИ І МІЖНАРОДНОЇ СТАБІЛЬНОСТІ В УМОВАХ «ЕКОЛОГІЧНИХ ВІЙН» ХХІ СТОЛІТТЯ
}

\author{
Ю.І. Калюжна \\ Харківський національний педагогічний університет імені Г.С. Сковороди
}

В статті здійснюється спроба, спираючись на прогностично-аналітичні проекти провідних експертів сучасної гуманітаристики (3. Бауман, А. Безгодов, Л. Браун, О. Дюенсен, С. Постел, Е. Уілсон, К. Кванг Фун та ін.), визначити локальні та глобальні ризики від наслідків зміни клімату та незворотності екологічних трансформацій XХІ століття. Акиентовано увагу на тому, щзо в умовах «надзвичайної кліматичноекологічної ситуацї̈» (масштабні природні катаклізми, стихійні лиха, голод, криза прісної води, масова міграчія, епідемї тощо) - основним джерелом соціально-політичної напруги та міжнародної дестабілізації стане боротьба за «базові ресурси» (продовольство, вода, медичне забезпечення, території придатні для життя та ін.). Вочевидь, «Війни за Воду», «Голодні Війни» та «Війни за Життєвий Простір» - стануть потужними генераторами глибокої дестабілізачії в окремих регіонах світу, провокуючи суспільно-політичні кризи, військові конфлікти, гуманітарні катастрофи та крупно масмтабні міграційні прочеси $і$ визначатимуть формат внутрішньої та зовнішньої політики держав в найближчому майбутньому.

Ключові слова: зміни клімату, екологічні трансформації, кліматично-екологічні проблеми, локальні та глобальні ризики, суспільно-політичні протести, соціальнополітичні кризи, політична напруга, державна безпека та міжнародна стабільність, «криза води», «продовольчий дефіцит», масова міграція, екологічні біженці та кліматичні мігранти, «кліматично-екологічні війни».

\section{К ВОПРОСУ ГОСУДАРСТВЕННОЙ БЕЗОПАСНОСТИ И МЕЖДУНАРОДНОЙ СТАБИЛЬНОСТИ В УСЛОВИЯХ «ЭКОЛОГИЧЕСКИХ ВОЙН» ХХІ ВЕКА}

\section{Ю.И. Калюжная}

В статье осуществляется попытка, опираясь на прогностично-аналитические проекты ведущих экспертов современной гуманитаристики (3. Бауман, А. Бегодов, Л. Браун, О. Дженсен, С. Постел, Э. Уилсон, К. Кванг Фун и др.), определить локальные и глобальные риски от последствий изменения климата и необратимости экологических трансформаций XXI столетия. Акиентировано внимание на том, что в условиях «чрезвычайной климато-экологической ситуации» (масштабные природные катаклизмы, стихийные бедствия, голод, кризи пресной воды, массовая миграция, эпидемии и т.п.) основным источником сочиально-политического напряжения и международной дестабилизации становится борьба за «базовые ресурсы» (продовольствие, вода, медицинское обеспечение, территории пригодные для жизни и др.). Очевидно, «Войны за Воду», «Голодные Войны» и «Войны за Жизненное пространство» - станут мощьными генераторами глубокой дестабилизащии в отдельных регионах мира, провочииуя 
общественно-политические кризисы, военные конфликты, гуманитарные катастрофы и крупномасштабные миграционные процессы и определят формат внутренней и внешней политики государств в ближайшем будущем.

Ключевые слова: смена климата, экологические трансформачии, экологические проблемы, локальные и глобальные риски, общественно-политические протесты, сочиально-политические кризисы, политическое, государственная безопасность и международная стабильность, «кризис водыл, «продовольственный дефицит», массовая миграџия, экологические беженцы и климатические мигранты, «климата-экологические войнbl».

\section{ONCERNING THE ISSUE OF STATE SECURITY AND INTERNATIONAL STABILITY IN THE ENVIRONMENTAL ECOLOGICAL WAR CONDITIONS}

\section{J. Kalyuzhna}

In this article, an attempt is made to identify local and global risks from the effects of climate change and the irreversibility of environmental transformations of the 21st century, basing on predictive-analytical projects by leading experts in contemporary humanities (Z. Bauman, A. Bezgodov, L. Brown, O. Jensen, S. Postel, E. Wilson, K. Kwang Foon, and others). The author states that in a globalization era conditions, the demarcation line of human inequality between the rich and the poor just deepens. Developed countries are able to use economic growth to deal the effects of climate change and adapt to environmental transformations, while less developed countries are receiving even more waste dumping and pollution, which certainly is becoming an additional factor in socio-political tensions and destabilization. Constant poverty and increasing of economic gap pose a real threat to social solidarity and undermine political stability, both nationally and internationally.

Attention is drawn to the fact that in the context of extreme climatic and ecological situation (large-scale natural cataclysms, natural disasters, famine, fresh water lack crisis, mass migration, epidemics, etc.) the main source of socio-political tension and international destabilization is the struggle for «basic resources» (food, water, medical supplies, livable areas, etc.). The obvious antinomy and asymmetry of modern politics in the environmental issue, combined with the increase in the level of political comprehension of the people, will inevitably lead to an explosion of socio-political tension. As a result riots, protests, revolutions, wars will become symptomatic markers of the 21st century. The Water Wars, The Hunger Wars, and the Living Space Wars will be powerful generators of deep destabilization in individual regions of the world, causing socio-political crises, military conflicts, humanitarian disasters and largescale migration processes, and also determining the format of internal and foreign policy of the states in the near future. Global integration and prioritization of the environmental issue is the only way to escape the global social tragedy of the «Global Environmental War for Survival» for Modern Civilization.

Key words: climate change, environmental transformations, climate and environmental problems, local and global risks, socio-political protests, socio-political crises, political tension, national security and international stability, «water crisis», «food deficit», mass migration, environmental refugees and climate migrants, «climate-ecological wars».

Постановка проблеми. Симптоматичними маркерами «глобального безладу» XXI століття $є$ - масові суспільні-політичні протести, - «сучасний безлад у світі в широкому сенсі є наслідком нового факту: сьогодні світ 
політично пробуджується до усвідомлення нерівності людського існування. Ще порівняно недавно величезна більшість людства фаталістично мирилася iз соціальною нерівністю. ... Тепер становище докорінно змінилося. Поширення грамотності й особливо дія сучасних комунікацій привели до безпрецедентного зростання рівня політичної свідомості мас» (Бжезінський, 2006, с. 48), й що вкрай важливо, - «Це більше протести проти майбутнього, яке викликає побоювання, i проти теперішнього, яке викликає обурення» (Бжезінський, 2006, с. 140), так в означеному контексті - «Арабська весна» (2011), «Захопи Уолл-Стріт» (2011), «Антикорупційний Рух Індії» (2011), «Соціальна справедливість Бразилії» (2013), «Свромайдан» (2013), Brexit (2016) та анти-Brexit (2016-2019), «Рух Жовтих Жилетів» (2018-2019) та інші прояви вуличних протестів XXI століття - попри варіативність суспільнополітичної природи (боротьба за політичні права, соціальну справедливість, вирішення економічної, корупційної, міграційної кризи тощо) виявляють інтегративний паттерн глобального порядку, - ігнорування або зволікання політичними елітами 3 конвертацією суспільних запитів в конкретні політико-практичні рішення, - продукує дифузію ірраціонально-радикальних настроїв в суспільстві, загрожує дисфункцією політичної системи держави, а відтак, - корелює 3 питаннями державної безпеки та міжнародної стабільності.

Незворотність кліматичних змін та масштаб екологічних катастроф «глобалізаційної доби» лише поглиблюють демаркаційну лінію нерівності людського існування між «багатими» i «бідними», - розвинені країни 3 потужною економічно-промисловою базою, завдяки механізмам міжнародної торгівлі, фактично перенесли забруднення та викиди парникових газів до країн, що розвиваються, - промисловість яких функціонує за рахунок дешевої робочої сили та дешевої «брудної» енергетики; таким чином, розвинені країни отримали можливість використовувати економічне зростання для боротьби 3 наслідками змін клімату та адаптації до екологічних трансформацій, в той час, як менш розвинуті країни - отримали 
ще більше викидів та забруднення довкілля, що стає додатковим фактором небезпеки та нестабільності, як на державному так і на міжнародному рівні. За даними експертів, в сучасному світі чисельність людей, які живуть в умовах бідності постійно збільшується, існування 70\% 3 них цілком або частково залежать від природних ресурсів, що робить їх особливо вразливими до наслідків екологічних трансформацій, останнім часом лише 9 країнам (що становить 4\% населення світу) вдалось скороти розрив між багатими та бідними (в той час як 80\% населення світу збільшили цю нерівність) - постійна бідність та зростання економічного розриву становлять реальну загрозу соціальній згуртованості та підривають політичну стабільність (The Green Economy Coalition, 2010, p. 4).

Потужність та синергія вуличних протестів початку XXI століття інтенсифікували в академічних колах дискусію, щодо соціально-політичної інженерії майбутнього світового порядку в умовах глобалізаційних кліматично-екологічних викликів, зокрема, - як забезпечити фундаментальні принципи державної безпеки та міжнародної стабільності в умовах «екологічних війн» майбутнього? Адже, очевидна антиномічність та асиметричність сучасної політики в екологічних питаннях в сукупності 3 зростанням рівня політичної свідомості мас неминуче призведе до соціальнополітичної напруги, а згодом - бунтів, протестів, революцій - усвідомлення того факту, що «Кліматичні зміни непропорційно вплинуть на людей із різним рівнем доходів, гостро вражаючи передусім найбільш соціально незахищені суспільні верстви, які мають обмежений доступ до енергії, води, запасів їжі належної якості та інших послуг, зокрема, медичного обслуговування» (Горин, 2012) - не залишає жодної реальної альтернативи для екологічно свідомих громадян аніж змінити риторику мирних екологічних акцій та розпочати глобальну протестну компанію. Як зазначили провідні експерти Інституту суспільного розумінні ризиків Кок Кванг Фун та Олівія Дженсен «Якщо люди не реагують на кліматичні попередження, нам треба змінити повідомлення» (World Economic Forum, 2019). 
Аналіз актуальних досліджень. Масштаб і характер кліматичноекологічних аберацій XX - початку XXI століття обумовили необхідність широкої міждисциплінарної дискусії, так до профільних спеціалістів геофізичного дискурсу (екологів, кліматологів, океанологів, біологів, метеорологів, сейсмологів та ін.) долучились провідні експерти суспільногуманітарного сектору, зокрема, - Дж. Александер, Б. Баркер, 3. Бауман, У. Баумол, У. Бек, Ж. Бодрійяр, Л. Браун, І. Валлерстайн, Т. Веблен, Ф. Гватарі, Дж. Гібсон, Е. Гідденс, С. Гокінгс, Р. Голл, А. Гор, Ж. Делйоз, Ф. Джеймсон, Д. Дойч, I. Дюрон, В. Клаус, Н. Кляйн, Е. Колберт, Л. Колдуелл, П. Коломі, Е. Лаклау, К. Леві-Лебуайє, Ж.-Ф. Ліотар, Г. Макстон, Дж. Маркофф, Е. Масуда, А. Міракян, А. Мол, Ш. Муфе, Д. Найсбіт, О. Неклесса, Л. Ніколсон, У. Отс, С. Постел, Й. Рандернс, 3. фон Cipiaci-Вентрап, Г. Скотт, Г. Спарганер, Н. Стерн, Д. Стокольс, Г. Тернер, Е. Тоффлер, Дж. Уррі, Ф. Ферраротті, Н. Фрезер, Дж. Фрідман, М. Фуко, Р. Фюкс, Ю. Ной Харарі, Дж. Хау, Н. Хомський, Й. Хубер, Н. Штерн та багатьох інших.

В комунікативному просторі вітчизняної науки дескрипція та аналіз кліматично-екологічної проблематики представлена в М. Алексієвець, О. Андрєєв, В. Андронов, О. Білорус, О. Варго, О. Васюта, Т. Галушкіна,Т. Гардащук, О. Гарнець, М. Гладкий, Н. Гозак, А. Голіков, О. Горин, М. Грановська, О. Дацій, I. Дедю, Г. Дзяна, А. Дєгтяр, О. Дзюбенко, С. Домбровська, І. Жданова, О. Задубрівська, М. Згуровський, К. Карпенко, В. Керецман, М. Кисельов, В. Ковальчук, В. Крисаченко, Л. Курняк, О. Куценко, О. Лазор, В. Лісничий, А. Льовочкіна, В. Лук’янихіна, О. Момотова, В. Недурак, Н. Нижник, О. Осауленко, О. Перова, В. Рехкал, С. Романюк, С. Рудишин, К. Рудницка, Н. Усенко, О. Салтовський, А. Самодрин, Л. Сергієнко, І. Синякевич, В. Скребець, С. Ставчук, М. Тарасенко, В. Тертичко, Н. Томенко, Т. Туница, А. Урсула, А. Шумілова, Л. Юрченко, С. Яковенко, Я. Яценко та інших дослідників. 
Мета статті - визначити та проаналізувати, як глобальні зміни клімату та екологічні трансформації XXI століття позначаються на фундаментальних принципах державної безпеки та міжнародної стабільності.

Виклад основного матеріалу. Спираючись на грунтовну базу науководослідницького матеріалу сучасної гуманітаристики, можна визначити основні генератори геополітичної та геоекономічної напруги в XXI столітті: військово-політичні конфлікти, діяльність терористичних організацій, політичні та фінансово-економічні кризи, некерованість міграційних процесів, зростання соціальної нерівності, безробіття, бідності тощо, - втім, масштаб та прогресія глобальних кліматично-екологічних трансформацій, у вигляді: температурних аномалій, рутинізації природних катастроф урагани, повені, посухи, лісові пожежі, забруднення водойм і грунтів, збільшення територій непридатних для життя, дефіциту продовольства та питної води тощо - визнано найбільшими регіональними і глобальними тригерами нестабільності в сучасному світі. Так, за результатами щорічної доповіді The Global Risks Report, було визначено найвірогідніші ризики на 2019 рік: 1) екстремальні погодні явищза, 2) відмова від рішучих дій у боротьбі з наслідками кліматичних змін, 3) масштабні стихійні лиха (землетруси, цунамі, вулканічні виверження, геомагнітні бурі тощзо), 4) масові випадки шахрайства та викрадення даних, 5) крупномасштабні кібератаки, 6) погіршення довкілля в наслідок техногенних катастроф та стихійних лих, 7) крупна масштабна вимущена міграція, 8) значна втрата біологічного різноманіття та порушення екологічних систем, 9) криза питної води, 10) крах активів великої економіки (World Economic Forum, 2019); - як бачимо, $7 \quad 3 \quad 10$ є кластерами кліматично-екологічної проблематики.

На сьогодні, цілком очевидно, наслідки «токсичного впливу» Сучасної Цивілізації на клімат і екологію Землі не вдалось спинити ані Декларацією Конференції ООН з проблем навколишнього середовища (Стокгольм, 1972), ані Доповіддю конференції ООН з навколишнього середовища і розвитку 
(Ріо-де-Жанейро, 1992), ані Рамковою конвенцією ООН з змін клімату та прийняттям Кіотського Протоколу (Кіото, 1997), ані Хартією Землі (2000), ані Йоганнесбурзькою декларацією сталого розвитку (Йоганнесбург, 2002), ані Всесвітньою Конференцією ООН зі змін клімату (Париж, 2015), ані Самітом ООН з сталого розвитку (Нью-Йорк, 2015), ані іншими амбітними проектами, що стали підгрунтям для глобального концепту «сталого розвитку» заснованого на принципах - справедливого розподілу багатства, економічної рівності та справедливості, рівності між поколіннями, попереджувального підходу, права на розвиток, урахування зовнішніх факторів, міжнародного співробітництва, міжнародної відповідальності, інформації, участі та відповідальності, сталого виробництва та споживання, стратегічного, скоординованого і комплексного планування, обгрунтованого переходу, переоцінки добробуту, гендерної рівності, збереження біорозмаїття та запобігання забрудненню будь-якої частини навколишнього середовища (Время глобальных действий для людей и планеты, 2015); - ані поодинокими «екологічними практиками» окремих екологічно свідомих особистостей Лоіс Гіббс, Альберт Гор, Джейн Гудолл, Едахіро Дзюнко, Леонардо Ді Капріо, Рейчел Карсон, Кароліна Лукас, Вангарі Маатаі, Деніс і Донелла Медоуз, Сандра Постель, Марк Руффало, Маріна Сілва, Боян Слат, Уілл і Джейден Сміти, Грета Тунберг, Крістофер Флавін, Морган Фріман та багато інших, - слід визнати, для вирішення глобальних кліматично-екологічних проблем потрібно набагато більші, ніж все щзо було зроблено до ияього часу «Враховуючи глобальний характер і стрімке зростання створених людством проблем, усвідомлюючи, що незворотна точка може бути пройдена в найближчому майбутньому, обмежитись напівмірами не вдасться. Видобуток сланцевого газу найближчим часом позбавить нас води, поля соєвих бобів та плантації олійних пальм - дощових лісів, викиди вуглецевого газу - звичної атмосфери. ... Практично все що ми робимо, наносить шкоду біосфері, навколишнє середовище стає все менш стабільним та сприятливим, а наше майбутнє в довгостроковій перспективі - все більш туманним» (Уилсон, 
2017, с. 10), а відтак, - «Просто роблячи щось «краще» для довкілля ми не зупинимо руйнування екологічних взаємозв’язків, від яких залежать наше харчування та здоров’я. Просте покращення нашої діяльності не стабілізує атмосферу. Воно не зупинить зменшення запасів водних ресурсів чи зростання рівнів океанів. Не поверне воно й арктичних льодовиків. ... Нам вкрай потрібно - і часу для цього залишається дедалі менше - зрозуміти, яким чином змінити напрямок руху для власної безпеки, безпеки наших нащадків та безпеки всіх інших видів, які є єдиними відомими нашими супутниками у всесвіті. I поки ми займатимемося цим складним завданням, ми також маємо підготувати суспільство до майбутнього, яке може принести труднощі та виклики, складніші за будь-які 3 тих, перед якими стояло людство до цього часу» (World Watch Institute, 2013).

Власне, сценарії майбутнього «Нового світового безладу» (Бауман, 2008, с. 48) обумовленого «надзвичайною кліматично-екологічною ситуацією» виглядають вкрай драматично, - Людство очікують локальні, а згодом і глобальні «Екологічні Війни», каталізаторами яких стануть масштабні природні катаклізми, стихійні лиха, голод, криза прісної води, масова міграція, епідемії тощзо. Отже, цілком реалістичний сценарій найближчого майбутнього це - не конкуренція за технічно-наукові інновації в сфері штучного інтелекту, колонізації космосу, інформаційнокомунікаційного зв’язку, транспорту, медицини, а реальна i жорстока боротьба за продовольство, воду та території придатні для життя - саме боротьба за «базові ресурси» й буде визначати формат внутрішньої $i$ зовнішньої політики сучасних держав найближчим часом.

Так, за розрахунками еколога-аналітика Лестера Брауна, у XXI столітті на глобальній арені розгортатимуться справжні «Голодні Війни», - «Welcome to the 21st-century food wars», саме так автор численних фундаментальних досліджень 3 екологічної проблематики проголошує про настання «нової геополітики дефіuуиту продовольства» (Brown, 2011) - «Жодна країна не наділена імунітетом, який б захищав іï від наслідків скорочення постачання 
продовольства» (Brown, 2011), адже наслідки кліматичних змін і масштаб екологічних катастроф неминуче призведуть до «продовольчої кризи», як наслідок - протести, бунти, революції, війни, - голод - цฺе ц̌ є найбільща загроза майбутній глобальній безпеці та стабільності. Браун зазначає, індекс цін на продовольство, які досліджує ООН, 3 року в рік долають максимальні показники, постійне зростання цін у поєднанні з демографічним ростом, зниженням врожаїв та природними катаклізмами, провокують продовольчий дефіц̧ит - дефіц̧ит стає новою нормою; втім, і що вкрай важливо, - в сучасному поляризованому світі, підвищення ціни на хліб на декілька відсотків, відчуватиметься по-різному: для заможних жителів розвинених країн, це буде «неприємно, викликатиме роздратування», проте, не критично, «але для 2 мільярдів самих бідних людей планети, які витрачають 50-70\% своїх доходів на продукти харчування, це стрімке зростання цін може означати перехід від двох блюд на день до одного. Ті хто ледь тримаються на нижніх сходинках глобальних економічних сходів, ризикують повністю втрати контроль» (Brown, 2011). Браун стверджує, продовольчий дефіцит вже $\epsilon$ реальністю 3 конкретними політичними наслідками, і застерігає: «Якщо потрясіння, з якими зіткнулись диктатори Зін аль-Абідін бен Алі в Тунісі, Хосні Мубарак в Єгипті та Муаммар Каддафі в Лівії (країни, що імпортують 90 відсотків свого зерна), - це не кінець історії, а лише їі початок? Готуйтесь, як фермери, так і міністри закордонних справ, до нової ери, у якій світовий дефіцит продовольства все більше формуватиме глобальну політику» (Brown, 2011).

Ще одним джерелом нестабільності в майбутньому $\epsilon$ - «глобальна криза прісної води», - безпрецедентне зростання світової економіки наприкінці XX - початку XXI століття помножене на цикли демографічних вибухів, призвели до масштабного збільшення антропогенного навантаження на екосистеми та природні водні об’єкти, - і як стверджує журналіст-еколог, автор численних публікацій 3 проблематики «дефіциту води», керівник Global Water Policy Project в США Сандра Постел - «Варто забути про нафту. 
Справедливий розподіл прісної води стає такою ж вибуховою та далекосяжною політичною головоломкою, як $і$ глобальні зміни клімату» (Global Water Policy Project, 2019). «Проблеми, пов’язані з споживанням води та іiі дефіцитом, настільки загострились в останні десятиліття, що почали розглядатись як одне з самих значних свідоцтв загальної кризи цивілізації. Вони є фактором, що стримують розвиток багатьох країн, джерелом міждержавних конфліктів і нестабільності. Дефіцит води знижує якість життя, поряд з бідністю стає причиною антисанітарії та росту захворюваності населення. Деградація багатьох водних об’єктів - це самий яскравий індикатор загального екологічного неблагополуччя на планеті» (ДаниловДанильян и Лосев, 2006, с. 200). На критичності питання «водного дефіциту» наголошують й експерти World Resources Institute, які спираючись на дані 3 167 країн спроектували кілька моделей можливих кліматичних i соціоекономічних трансформацій, та дійшли висновку: - через зміни клімату кожна п'ята краӥна зіткнеться з гострою нестачею води до 2040, також дослідниками було презентовано рейтинг «Water Stress by Country: 2040», до якого потрапили 33 країни найбільш вразливі до «гострого дефіциту води» (найгостріше ця проблема постане перед Бахрейном, Кувейтом, Ізраїлем, Сан-Марино, Палестиною, Катаром, ОАЕ, Саудівською Аравією, Оманою, Ліваном) (World Resources Institute, 2015). Вочевидь, виснаження водних ресурсів, погіршення якості питної води та зростання іiі дефіциту в майбутньому призведе до «Війн за Воду», які стануть потужними генераторами глибокої дестабілізації в окремих регіонах світу, провокуючи суспільно-політичні кризи, військові конфлікти, гуманітарні катастрофи та крупно масштабні мігращійні процеси, - як зазначив в своїй доповіді Генеральний секретар ООН Антоніу Гутерріш: «40\% населення Землі вже в той чи іншій мірі відчувають «гострий дефіцит води. На 2030 рік із-за нестачі води близько 700 мільйонів людей можуть стати біженцями» (Новини ООН, 2018). 
Очевидно, що турбулентність кліматично-екологічних трансформацій XXI століття провокує дефіцит продовольства та питної води, проте головним тригером, що запускає ланцюгову реакцію масштабної майбутньої продовольчої та водної кризи, $є$ - стрімке зростання чисельності населення Землі, адже сучасні демографічні індекси (кількість новонароджених та тривалість життя) вимагають збільшення територій сільськогосподарського призначення та більш інтенсивної їх експлуатації, - «3 середини століття територія вирощування зернових культур, скоротилася на 19\%, тоді як кількість жителів Землі зросла на 132\%. Зростання населення негативно позначається на сільськогосподарських територіях, скорочує їх продуктивність та навіть зовсім виводить їх з обігу. Оскільки площа орних земель на душу населення скорочується, все більше країн опиняється перед загрозою неможливості забезпечити себе продуктами харчування» (Біляцький та Ярова, 2006, с. 147), відтак, - саме від здатності держав оперативно та ефективно вирішувати проблеми продовольчо-водного забезпечення буде залежати питання державної безпеки та міжнародної стабільності. Досліджуючи наслідки антропогенного впливу на нашу планету Гайя Вінс наголошує, - «із-за характеру використання людством земельних ресурсів рослинні зони перетворюються на безплідні пустелі. Інтенсивне сільське господарство та зростання населення в посушливих регіонах прискорюють процеси опустелівання. Поширення пустель руйнує грунти, що призводить до масової міграції сільських жителів до міських нетрів та росту бідності. По всій планеті опустелівання щорічно сприяє деградації більше 12 млн. гектарів орних земель. Порядка 40 \% всієї території Африки вже зазнали цих процесів, i аналітики попереджають, що к 2025 року дві треті орних земель континенту можуть бути втрачені» (Винс, 2016, с. 209). Вочевидь, зміни клімату та екологічні трансформації, процеси опустелівання та ерозії грунтів, дефіцит продовольства та криза питної води - неминуче спровокують масові міграційні процеси, - «кліматичні біженці» та «екологічні мігранти» у боротьбі за «життєвий простір» та базові 
ресурси стануть основним джерелом напруги та нестабільності в ХХІ століття. «Якщо приймати до уваги те, що більшість 3 тих 2,4 млрд. людей, які збільшать населення світу до 2050 року, з’явиться на світ в країнах 3 низьким горизонтом води, потоки біженці, що рятуються від спраги, скоріш за все, стануть звичним явищем. Таких біженців буде особливо багато в безводних та посушливих регіонах, чисельність населення яких швидко переростає можливості забезпечення водними ресурсами. Ці райони впадають в гідрологічні злидні» (Браун, 2010, с. 94). Фактично, для 25 мільйонів людей «Війна за Життєвий простір» вже розпочалась, - так, за оцінками Institute for Environment and Human Security: «цього річ 25 мільйонів людей в цілому світі були змушені залишати свої місця проживання 3 причин невідповідного довкілля (це у порівнянні 322 мільйонами біженців через громадянські війни та різного роду переслідування)», та надають невтішні прогнози, щодо кількості майбутніх кліматичних біженців, «чисельність яких у 2050 році - зросте до 250 мільйонів» (United Nations University. Institute for Environment and Human Security, 2019).

\section{Висновки та перспективи подальших досліджень. Попри} аргументовані висновки сучасних науковців та попередження про ризики настання глобальної кліматично-екологічної катастрофи, яка може спровокувати локальні соціально-політичні кризи, - протести, бунти, революції, війни в окремих регіонах світу, через дефіцит базових ресурсів (продовольства, питної води, медичного забезпечення, територій придатних для життя тощо), а згодом й глобальну соціальну трагедію - «Глобальну Екологічну Війну за Виживання», - на сьогодні чимало країн «поводить себе егоїстично та не поспішає витрачатись на антикризові заходи загальносвітового масштабу, вважаючи таку поведінку дозволенною, до того часу доти ці проблеми не торкнуться їх безпосередньо. Те саме відбувається і по лінії ратифікації низки міжнародних угод, регламентуючих та обмежуючих втручання в екосистеми, видобуток сировини, промисловість, 
сільське господарство, військово-промисловий комплекс. Більшість політичних суб’єктів сучасного світу не поспішає себе обмежувати» (Безгодов, 2016, с. 13), проте, як зазначив Пан Гі Мун - «Ми повинні особливо допомагати найбіднішим i найбільш вразливим прошаркам населення. Зміни клімату посилюють ризики для сотні мільйонів людей ... Дев’ять 3 десяти смертей в результаті стихійних лих приходяться на країни 3 низьким і середнім рівнем доходів. Ці держави потребують особливої уваги. Втім зниження ризиків від лих - в інтересах всіх і справа кожного» (UNISDR, 2015 , c. 42).

Цілком очевидна необхідність пріоритезації екологічного питання в світовому політико-економічному просторі та усвідомлення необхідності загальносвітової інтеграції заради збереження Сучасної Цивілізації і можливості подальшої еволюції Людства у гармонії з Природою Землі, - на відповідальності і співпраці наголошує й провідний експерт з екологічної політики Лестер Браун - «Нам потрібно зробити вибір між майбутнім, в якому відбуватиметься постійне зростання цін на продовольство, поширюватиметься голод та наростатиме політична нестабільність, i майбутнім, в якому буду спостерігатись стабілізація цін на продовольство та різко скоротяться залежність від нафти і викиди вуглецевих газів» (Браун, 2010, с. 85), і додає «Якщо провідні країни не оголосять загальну мобілізацію заради регулювання чисельності населення, стабілізації клімату та запасів підземних вод, заради консервації грунту, захисту сільськогосподарських угідь ..., загроза буде лише зростати» (Браун, 2010, с.74).

\section{ЛІТЕРАТУРА}

1. Бауман, 3., 2008. Глобалізачія. Наслідки для людини і суспільства. Переклад 3 англійскої І. Андрущенка. Київ: Вид. дім «Києво-Могилянська академія».

2. Безгодов, А. 2016. Планетарная рента как инструмент решения глобальних проблем. СПб.: Питер.

3. Бжезінський, 3., 2006. Вибір: світове панування чи світове лідерство. Переклад 3 англійскої А. Іщенка. Київ: Видавничий дім «Києво-Могилянська академія».

4. Біляцький, С. та Ярова, Н., 2006. Соціальні наслідки зростання населення Землі. Політичний менеджмент, 6, с.144-152. 
5. Браун, Л., 2010. Как избежать климатических катастроф? План Б 4.0: спасение циивилизащии. Перевод с английского А. Калинин, И. Калинин, С. Воронцов. Москва: Эксмо.

6. Винс, Г. 2016. Приключения в антропочене. Путешествие к сердиу планеты, которую мы создали. Москва: Колибри.

7. Горин, О., 2012. Нова кліматична ера: глобальне потепління може мати для України як негативні, так $i$ позитивні наслідки. [online] Доступно: https://tyzhden.ua/Society/55859 [Дата звернення 19 січень 2019].

8. Данилов-Данильян, В. и Лосев, К. 2006. Потребление воды:: экологический, экономический, сочиальныий и политический аспекты. Москва: Наука.

9. Новини ООН, 2018. У двух миллиардов человек нет чистой питьевой водьл. [online] Доступно: https://news.un.org/ru/story/2018/03/1325832 [Дата звернення 5 січень 2019].

10. UNISDR, 2015. Протоколь. Третья Всемирная Конференция ООН По Снижению Риска Бедствий. [online] Доступно: https://www.unisdr.org/files/45069_proceedingsthirdunwcdrrru.pdf [Дата звернення 11 січень 2019].

11. Время глобальных действий для людей и планеты, 2015. Саммит по устойчивому развитию. Преобразование нашего мира в интересах людей и планеты. [online] Доступно: $\quad$ https://www.un.org/sustainabledevelopment/ru/wpcontent/uploads/sites/5/2015/08/Overview_Sustainable_Development_Summit.pdf [Дата звернення 11 січень 2019].

12. Уилсон, Э., 2017. Будущее Земли. Наша Планета в борьбе за жизнь. Перевод с английского С. Чернин. Москва: Альпина нон-фикшн.

13. Brown, Lester R., 2011. The New Geopolitics of Food. Foreign Policy. [online] Available at: https://foreignpolicy.com/ [Accessed 23 January 2019].

14. Global Water Policy Project, 2019. [online] Available at: https://www.globalwaterpolicy.org/ [Accessed 18 January 2019].

15. United Nations University. Institute for Environment and Human Security, 2019. [online] Available at: http://www.ehs.unu.edu/ [Accessed 22 January 2019].

16. World Watch Institute, 2013. State of the World 2013: Is Sustainability Still Possible? [online] Available at: www.worldwatch.com [Accessed 16 January 2019].

17. World Economic Forum, 2019. The Global Risks Report 2019. [online] Available at: https://www.weforum.org/reports/the-global-risks-report-2019 [Accessed 2 February 2019].

18. The Green Economy Coalition, 2010. The Green Economy Pocketbook: The case for action. [online] London Available at: http://www.cawater-info.net/greengrowth/files/green-economy-pocketbook.pdf [Accessed 12 January 2019].

19. World Resources Institute, 2015. Water Stress by Country: 2040. [online] Available at: https://www.wri.org/blog/2015/08/ranking-world-s-most-water-stressed-countries-2040 [Accessed 16 January 2019].

\section{Інформація про автора}

Калюжна Юлія Іванівна - кандидат політичних наук, викладач кафедри політології, соціології і культурології Харківського національного педагогічного університету імені Г.С. Сковороди; e-mail: kaliuzhna.yulia@gmail.com; ORCID: https://orcid.org/0000-00027344-410X. 